\title{
Kayseri Selçuklu Uygarlığı Müzesinde Bulunan Bir Grup Kemer Tokası ${ }^{1}$
}

\author{
Hatice ÜNLERŞEN ${ }^{1}$ (D) Ahmet ÇAYCI ${ }^{2}$ \\ 1. Doktora Öğrencisi, Necmettin Erbakan Üniversitesi, Sosyal Bilimler Enstitüsü, İslam Tarihi ve Sanatları Anabilim Dalı, \\ Konya, Türkiye, hatice.kulus@yandex.com (Sorumlu Yazar/Corresponding Author)
}

2. Prof. Dr., Necmettin Erbakan Üniversitesi, Sosyal ve Beşeri Bilimler Fakültesi, Sanat Tarihi Bölümü,

Konya, Türkiye, ahmetcayci@gmail.com

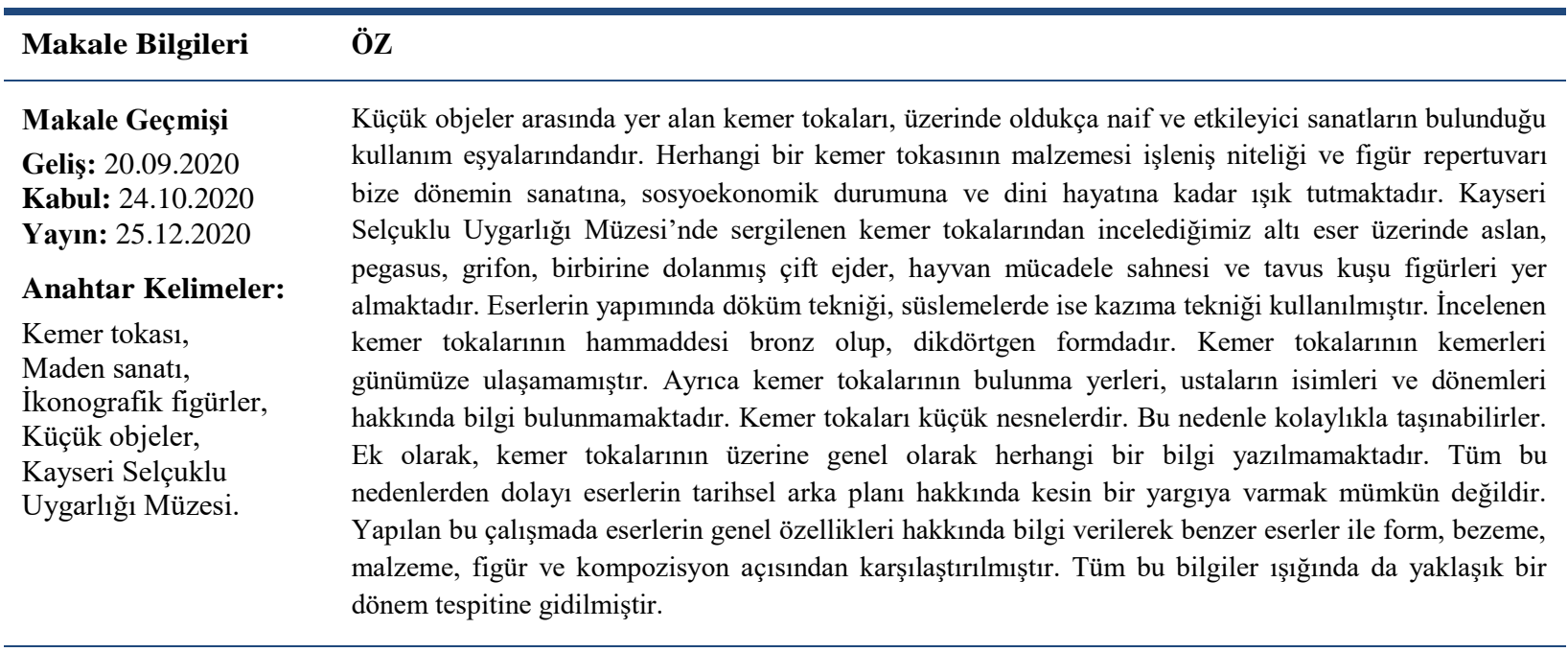

A Group of Belt Buckles in the Kayseri Seljuk Civilization Museum

\begin{tabular}{|c|c|}
\hline Article Info & ABSTRACT \\
\hline $\begin{array}{l}\text { Article History } \\
\text { Received: } 20.09 .2020 \\
\text { Accepted: } 24.10 .2020 \\
\text { Published: } 25.12 .2020 \\
\text { Keywords: } \\
\text { Belt buckle, } \\
\text { Metal arts, } \\
\text { Iconographic figures, } \\
\text { Small objects, } \\
\text { Kayseri Seljuk } \\
\text { Civilization Museum. }\end{array}$ & $\begin{array}{l}\text { Belt buckles, which are among small objects, are among usage items on which there are very naive and } \\
\text { impressive arts. The material, the processing methods, and the repertoire of figures of any belt buckle } \\
\text { shed light on the art, socioeconomic status, and religious life of the period. There are lion, pegasus, } \\
\text { griffon, twisted double dragon, an animal fight scene, and peacock figures on the six artifacts that we } \\
\text { examine from the belt buckles exhibited in Kayseri Seljuk Civilization Museum. The casting technique } \\
\text { was used in the production of the works, and the scraping technique was used in the ornaments. The raw } \\
\text { material of the belt buckles examined is bronze and in rectangular form. The belts of the belt buckles } \\
\text { have not reached nowadays. Besides, there is no information about the find places, names of the masters, } \\
\text { and periods of belt buckles. Belt buckles are small objects. Therefore, they can be transported easily. } \\
\text { Additionally, no information is inscribed generally on belt buckles. For all these reasons, it cannot } \\
\text { possible to reach an exact judgment about the historical background of the works. In this study, } \\
\text { information about the general features of the works was given and compared with similar works in terms } \\
\text { of form, decoration, material, figure, and composition. In light of all this information, an approximate } \\
\text { period was determined. }\end{array}$ \\
\hline
\end{tabular}

Atıf/Citation: Ünlerşen, Hatice - Çaycı, Ahmet. "Kayseri Selçuklu Uygarlığı Müzesinde Bulunan Bir Grup Kemer Tokası". Selçuklu Medeniyeti Araştırmalarl Dergisi (SEMA) 5 (Aralık 2020), $110-127$. https://doi.org/10.47702/sematr.2020.7

"This article is licensed under a Creative Commons Attribution-NonCommercial 4.0 International License (CC BY-NC 4.0)"

\footnotetext{
${ }^{1} \mathrm{Bu}$ makale, Necmettin Erbakan Üniversitesi Sosyal Bilimler Enstitüsü İslam Tarihi ve Sanatları Anabilim Dalı’nda 2015 yılında tamamlanmış Kayseri Selçuklu Uygarlığı Müzesi’nde Bulunan Kemer Tokaları başlıklı yüksek lisans tezinin bir bölümünün genişletilmişşseklidir.
} 


\section{GíRiş}

İnsanın doğadaki kaynaklardan elde edildikten sonra dökülmek için eritilmeye, dövülmeye, kesilmeye, çeşitli şekillerde biçimlendirmeye uygun ve üzerinde türlü nakışlar yapmaya uygun olan madenlerin gerçek karakterini öğrenmesi metalürji tarihinin en büyük aşamalarından birini oluşturur. ${ }^{2}$

Arkeolojik kazılarda bulunan deliller 1şığında, madenin ilk defa işlenmesinin takriben 10.000 yıl önce Anadolu'da Diyarbakır/Ergani’nin Çayönü Höyüğü civarında başladığı ortaya konmuştur. Çatalhöyük'te ise M.Ö.7000 yılında arıtılma işleminin ilk defa yapıldığı tespit edilmiştir. ${ }^{3}$ Bu bilgiler bize göstermektedir ki insanoğlu madeni çok erken bir zamanda keşfetmiş ve hayatının içerisinde kullanılır hale getirmiştir. Maden sadece günlük kullanım eşyaları, silah ekipmanları olarak değil, dekoratif amaçlı ya da süs eşyaları olarak da işleme tabi tutulmuştur.

$\mathrm{Bu}$ bağlamda kullanım eşyasının sanata dönüşmesi ile ortaya çıkan süs eşyalarından en göze çarpanı da şüphesiz kemer tokalarıdır. Kemer tokası iki kemer ucunun birleşmesini sağlayan nesnedir. Kemerin, tokası ile beraber bir bütün olarak sanat eseri olanlarının yanı sıra, çoğunluğunda esas önemli olan tokalardır. ${ }^{4}$

Kemer tokaları form ve biçim olarak Avrupa ve Asya'ya Hunların ve Avarların göçleriyle yayılmıştır. ${ }^{5}$ M.Ö. 4. yüzyıla ait tasvirler incelendiğinde İran bölgesinde İslam'ın gelişine kadarki dönemde kemer ve kemer tokalarının çoğunlukla erkeklerin kullandığı eşyalar olduğu görülmektedir. Kemer takan kadın tasvirleri ise çok nadirdir ve çoğunun önemli ölçüde Helenistik ve Roma stilinden etkilendiği görülmektedir. ${ }^{6}$

Part heykelleri ile 2. Şapur ve Hırbetü'l-Mefcer Sarayı'ndaki Halife Hişam ile Orhun Anıtları'ndaki Kültigin heykelinde farklı kemer biçimlerini bulmak mümkündür. ${ }^{7}$ Samarra Cevsâkü’lHakânî Sarayı'nda rastlanan yaban keçisi ve boğa figürü bulunan kemerin sarkaçlarında asılı kaması vardır. 10. yüzyıla ait Nişapur duvar resimlerinde süvari figüründe de sarkaçlı kemerler görülür. Gazne mermer kabartmaları ve Leşker-i Bazar Sarayı'nın taht salonunda bulunan resimde sıralanmış olan askerlerin belinde de kemerlere rastlanmıştır. ${ }^{8}$

Erken Roma döneminde askeri üniformanın bir parçası olan kemerler Diokletianus (284-305) ve I. Konstantinos (324-336)'un reformları süresince resmi kıyafetlerin bir parçası olmuştur. ${ }^{9}$ Orta Bizans dönemi tasvirlerinde kıyafet kıvrımlarının arasında varlığı ile yokluğu çok belirgin değilken Geç Bizans dönemindeki tasvirlerde kaftanların üzerinde beli kuşatan kemerler daha ön planda resmedilmiştir. ${ }^{10}$ Bizanslı yazarlar evlilik hediyeleri arasında gelinlere verilen kemerlerden söz

\footnotetext{
${ }^{2}$ Mehmet Zeki Kuşoğlu, Resimli Ansiklopedik Kuyumculuk ve Maden Terimleri Sözlüğü (İstanbul: Ötüken Neşriyat, 2006), 53.

3 İzzet Gündağ Kayaoğlu, Türkiye'de Sanatın Bugünü ve Yarını (Ankara: Hacettepe Üniversitesi Güzel Sanatlar Fakültesi Yayınları, 1985), 439.

${ }^{4}$ Mehmet Zeki Kuşoğlu, “Osmanlı Kemer ve Tokaları”, Dünkü Sanatımız Kültürümüz 279 (1994), 53-58.

5 James W Allan, Nishapur: Metalwork of The Early Islamic Period (NewYork: Metropolitan Museum of Art, 1982), 28.

${ }^{6}$ Peter Calmeyer, "Belts”, Encyclopedia Iranica (Encyclopædia Iranica Foundation, 1989), 130.

${ }^{7}$ Gülgün Köroğlu, "A Group of Belt Buckles From The Haluk Perk Museum Possible Belonging to The Anatolian Seljuks", 13th International Congress of Turkish Art (Budapest: Hungarian National Museum, 2009), 393-407.

${ }^{8}$ Özden Süslü, Tasvirlere Göre Anadolu Selçuklu Klyafetleri (Ankara: Atatürk Kültür, Dil ve Tarih Yüksek Kurumu, 1989), 155.

${ }^{9}$ Alexander Kazhdan, "Belt”, The Oxford Dictionary of Byzantium (Oxford University Press, 1991), 280.

${ }^{10}$ Maria G Parani, Optional Extras or Necessary Elements? Middle And Late Byzantine Male Dress Accessories

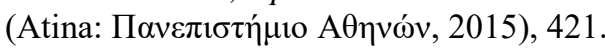


etmektedirler. Washington'daki Dumbarton Oaks Koleksiyonu'nda, diğeri ise Paris'teki Louvre Müzesi'nde iki evlilik kemeri bulunmaktadır. ${ }^{11}$

Türk toplumunun göçebe karakteri ile uyuşan elbiselerinde bellerine taktıkları sarkıntıları olan kemer, Göktürklerde, Uygurlarda ve Gaznelilerde kullanılagelmiş, Avrupa'ya ulaşan Türklerde ve Selçuklularda da çok kullanılır olmuştur. Uygurlar ve Müslüman Türklerde karşılaşılan kemer ve benzeri öğelerin bezeme unsurları değişmiş, hayvan figürlerinin yerini bitki veya koçboynuzu motifi yer almıştır. ${ }^{12}$

Selçuklu devrinden günümüze ulaşan takı sayısı oldukça azdır. Küçük hayvan figürleri şeklinde olan veya hayvan figürleriyle süslü kemer tokalarının, İran atölyelerinde üretilmiş olabileceği düşünülmektedir. ${ }^{13}$ Ani'de 2002 yılında yapılan kazıda bulunan bir kemer 12. yüzyılın sonu ile 13. yüzyılın ilk yarısına tarihlendirilmektedir. Eserin Büyük Selçuklu Devleti zamanında, Merv veya Rey civarına ait olduğu düşünülmektedir. ${ }^{14}$ Kubad-Abad Sarayı'nda yapılmış olan kazı çalışmasında ise 9 adet tokaya rastlanmıştır. Bunlardan dördü bronz, diğerleri ise demirdendir. Bronz olanlar kemer tokası, diğerleri ise askıdır. Tokaların tamamı dövme tekniği ile imal edilmiştir. ${ }^{15}$

Kemer tokalarının yapımında kullanılan başlıca madenler altın, gümüş, bakır, tunç, pirinç ve demir, doğada metalik ya da cevher olarak bulunmaktadır. ${ }^{16}$ İnsanlık tarihi kadar eski olan altın yumuşak, kolay ve soğukken işlenebilir bir özelliğe sahiptir. Altın, gümüş ve bakırla karışık olarak da bulunmaktadır. Altın ile gümüşün $1 / 5$ oranında karıştırılmasıyla oluşan alaşım beyaz altın olarak isimlendirilmektedir. Gümüş, altın gibi özellikle mücevhercilikte kullanılan kıymetli bir madendir. İşlenmeye çok müsait olan gümüş madeni doğada hem doğal hem de cevher olarak bulunmaktadır. Gümüş de altın gibi yumuşak bir madendir ve soğukken de çekiçlenebilir. ${ }^{17}$

Tabiatta yaygın olarak bulunan bakır cevheri arıtılan madenlerin başında gelir. Bakır tek başına iyi bir döküm malzemesi değildir. Bu nedenle bakıra kalay, kurşun yâda çinko karıştırılarak döküme daha dayanıklı bronz ve pirinç alaşımlar elde edilmektedir. ${ }^{18}$ M.Ö. 4. bin yılının sonlarında bakıra kalay cevheri karıştırılarak tunç alaşımı elde edilmiştir. Tunç madeninin tercih edilme özelliği ise hem dayanıklı hem de eridiği zaman kabarcıklanmamasıdır. Bu nedenle tunç döküme uygun bir madendir. ${ }^{19}$ Pirinç, genellikle $\% 30$ çinko ve $\% 70$ bakırdan oluşan sarı renkte bir alaşımdır. Bakır gibi levha haline getirilebilir ve tel yapılabilir. ${ }^{20}$ Pirinç, bakır pasına elverişli bir maden olduğu için ince bir şekilde kalay tabakasıyla kaplandıktan sonra özellikle mutfak eşyalarında kullanılabilmektedir. ${ }^{21}$ Demir, tabiatta doğal ya da cevher şeklinde bulunabilmektedir. Demirin cevherden ayrılabilmesi için

${ }^{11}$ Gülgün Köroğlu, “Bizans’ta Kadın ve Kadın Takıları”, Osmanlı Bankası Arşiv ve Araştırma Merkezi 24 (2010), 1-15.

${ }^{12}$ Nejat Diyarbekirli, Hun Sanatı (İstanbul: Milli Eğitim Bakanlığı Kültür Yayınları, 1972), 121.

${ }^{13}$ Gülgün Köroğlu, Anadolu Uygarlıklarında Takı (İstanbul: Türk Eskiçağ Bilimleri Enstitüsü Yayınları, 2004), 50.

${ }^{14}$ Nakış Karamağaralı, “Ani’de 2002 Yılında Ortaya Çıkarılan Yapı ve İçinde Bulunan Define”, Erdem 55 (2009), 93-115.

15 Alptekin Yavaş, "Kubad-Abad Sarayında Bulunan Kemer ve Askı Tokaları”, Turkish Studies-International Periodical For The Languages, Literature and History of Turkish or Turkic 7/3 (2012), 2635-2648.

${ }^{16}$ Ülker Erginsoy, "Maden Sanatı”, Eczacıbaşı Sanat Ansiklopedisi (Yap1-Endüstri Merkezi Yayınları, 1997), 1138-1147.

${ }^{17}$ Tevhide Özbağı, “Geleneksel Türk Takıları”, Türkler Ansiklopedisi (Yeni Türkiye Yay, 2002), 794.

${ }^{18}$ Mustafa Arlı, Beypazarı'nda Dövme Bakırcılık (İstanbul: Kültür ve Turizim Bakanlığı Millî Folklor Araştırma Dairesi Yayınları, 1984), 8.

${ }^{19}$ İzzet Gündağ Kayaoğlu, Bakır Kap Yapım ve Teknikleri: I. Dövme Tekniği (İstanbul: Anadolu Sanat Yayınları, 1984), 216.

${ }^{20}$ Hans Keller - Klaus Eichoff, Bakır ve Bakır Alaşımları, Çev. Şefik Güleç (İstanbul: İ.T.Ü. Yayını, 1969), 25.

${ }^{21}$ Ward Rachel, Islamic Metalwork (London: British Museum Press, 1993), 29. 
çok yüksek 1sı sağlayan arıtma firınları gerekmektedir. Demirin niteliği, içine karışan karbon oranına bağlıdır. Karbon oranı yükseldikçe demir sertleşir ve dayanıklılı̆̆ı $\operatorname{artar}^{22}$

Madeni eserlerin kullanım eşyasına ya da birer sanat eserine dönüşmesinde birçok araç gereç kullanılmaktadır. Üzerinde madeni dövmeye ve şekillendirmeye yarayan alete örs denir. Yapılacak işe göre çeşitli biçimlerde çelik örsler kullanılır. Örsün kalitesi eserin kalitesini etkileyeceğinden örs pürüzsüz ve cilalı olmalıdır. Madeni işlerken yükseltme ve çökertme işlemlerinde çekiçler kullanılmaktadır. Örsler gibi çekiçlerin de ağızlarının pürüzsüzce cilalı olması gerekmektedir. Madeni eserleri işlemede kullanılan örs ve çekicin yanı sıra nakış kalemi, pergel, makas, tokmak ve kıskaç gibi aletler de kullanılmaktadır. ${ }^{23}$

Tarihte tasfiye yoluyla cevherden maden elde etme işi gerçekleştikten sonra, madenler bollaşmış ve çeşitlenmiş, maden sanatının çeşitlenmesine yol açan diğer madeni hamleler birbirini izlemiştir. Tasfiyeden kısa bir süre sonra madenlerin potada eritilmesi, bunun ardından da erimiş madenlerin istenen biçimlerde hazırlanması, taş veya kil kalıplara dökülerek dondurulması yani "döküm” usulü keşfedilmiştir. Dökümün başarılması dövme tekniğinin gelişiminde oldukça önemli rol oynamıştır. Dövme tekniğinde iki tür usul kullanılmaktadır. Bunlardan biri çökertme diğeri ise toplamadır. ${ }^{24}$ Dövme usulünde, usta her parça ile tek tek uğraşmaktadır. Fakat döküm usulünde ise birden fazla kalıba ya da aynı kalıba birçok eser dökülebilmektedir. Yani zaman ve emek açısından bir birinden farklı özellikleri bulunmaktadır.

Madeni sanat eserlerinin hemen hemen hepsinde az ya da çok süsleme görülmektedir. Eser üzerindeki bu süslemeler uygulanacak tekniğe göre şekil almaktadır.

Madeni eserleri süsleme tekniklerinden biri olan çalma tekniği, ucu küt metal kalemlerle hafifçe bastırılarak uygulanır, yivler açılır ve yivin içindeki maden yerinden kesilip çıkarılmaz, yalnızca yivin iki tarafına itilir. ${ }^{25}$ Kazıma tekniğinde ise yivin içindeki maden kazılarak alınır. Madeni eserler üzerine kabartma aletleri ve çekiç kullanılarak, kabartma süslemelerinin yapıldığı tekniğe "repousse (çarpma, çakma) tekniğì" denir. ${ }^{26}$ Bir diğer süsleme tekniği ise delik-işi denilen diğer bir adı da ajur olan süsleme tekniğidir. ${ }^{27}$ Madeni eserler üzerinde yivler veya çukurlar açılmak suretiyle içerisinde başka maden kakılmasıyla elde edilen süsleme tekniğine "kakma tekniği" denilmektedir. Önemli olan eser ile kakılan maden arasında uyum olmasıdır. ${ }^{28}$ Kalınca gümüş veya altın tellerine istenilen şekle göre kesip kıvırarak birbirine lehimlemek suretiyle vücuda getirilen motiflerle süslü madeni işlere "telkâri" denir. ${ }^{29}$ Bir diğer süsleme tekniği ise dilimize savat diye geçen "sevad"dır. Manası karalamak demektir. Savat, her türlü geometrik şekil üzerine uygulanabilen tekniktir. ${ }^{30}$ Madeni eserler, değerli bir taş, cam veya mine dolgularla da süslenebilmektedir. Bunlar, eser üzerinde açılmış yuvalara veya lehimle tutturulan tel hücrelerine yerleştirilir. ${ }^{31}$

\footnotetext{
${ }^{22}$ Erginsoy, "Maden Sanatı.", 1140.

${ }^{23}$ Kayaoğlu, Bakır Kap Yapım ve Teknikleri: I. Dövme Tekniği, 227.

${ }^{24}$ Kayaoğlu, Bakır Kap Yapım ve Teknikleri: I. Dövme Tekniği, 228.

${ }^{25}$ Herbert Maryon, "Metal Working in The Ancient World”, American Journal of Archaeology 53/2 (1949), 93125.

${ }^{26}$ Fulya Eruz, Konuşan Maden: Tombak ve Gümüş Madeni Eserler Koleksiyonu (İstanbul: Yapı Kredi Yayınları, 1993), 33.

${ }^{27}$ Kuşoğlu, Resimli Ansiklopedik Kuyumculuk ve Maden Terimleri Sözlüğ̈̈, 65.

${ }^{28}$ Mehmet Zeki Kuşoğlu, “Dünden Bugüne Gümüş Kakma Sanatımız”, İlgi Dergisi 48 (1987), 32-35.

${ }^{29}$ Mehmet Zeki Kuşoğlu, “Telkâri”, İlgi Dergisi 45 (1986), 31-35.

${ }^{30}$ Kuşoğlu, Resimli Ansiklopedik Kuyumculuk ve Maden Terimleri Sözlüğ̈̈, 35.

${ }^{31}$ Can Kerametli, “Türk Maden Sanat,," Türk Yurdu 10 (1966), 14-32.
} 
Kayseri Selçuklu Uygarlığı Müzesi'nde bulunan kemer tokalarından figür bezeme açısından öne çıkan 50 adet kemer tokası incelenmiştir. ${ }^{32}$ Figür repertuvarına bağlı olarak 6 adet kemer tokası bu makale içerisinde irdelenecektir.

$\begin{array}{llll}\text { ENVANTER NO } & : \text { SUM } 361 & \text { ESERİN CINSİ } & \text { : Bronz } \\ \text { BOYUTLARI } & : 2,9 \text { x } 3,8 \mathrm{~cm} & \text { YAPIM TEKNİĞİ } & \text { : Döküm } \\ \text { BEZEME TEKNIKLERİ } & : \text { Kazıma } & \text { ESERİN DÖNEMİ } & \text { : Ortaçağ }\end{array}$

ESERIN TANIMI : Eser dikdörtgen şeklindedir. Eserin sağ tarafinda kemer bağlantısını sağlayan bir halka mevcuttur. Solda ise yine kemer bağlantısını sağlayan iki küçük halka vardır. Fakat iki halka arasında bulunması gereken pim ve diğer parçalar mevcut değildir. Eser üzerinde kabartma olarak başı cepheden gövdesi profilden verilen bir aslan figürü yer almaktadır. Dik kulaklar kazıma tekniği uygulanarak derin oyuklarla daha belirgin hale getirilmiştir. İri badem gözler açıktır. Yanaklar şişkince olup ağız kapalıdır. Baş gövdeye nispetle daha iridir. Yürür vaziyette olan aslanın kuyruğu ise yukarı doğru kıvrılmaktadır.

DEĞERLENDİRME : Yukarıda tanımladığımız eser üzerinde kazıma tekniğinin hâkim olması, aslan figürünün fiziksel betimlemeleri, form ve kompozisyon açısından eser, 11.-12.yy Selçuklu Dönemine daha yakın durmaktadır.

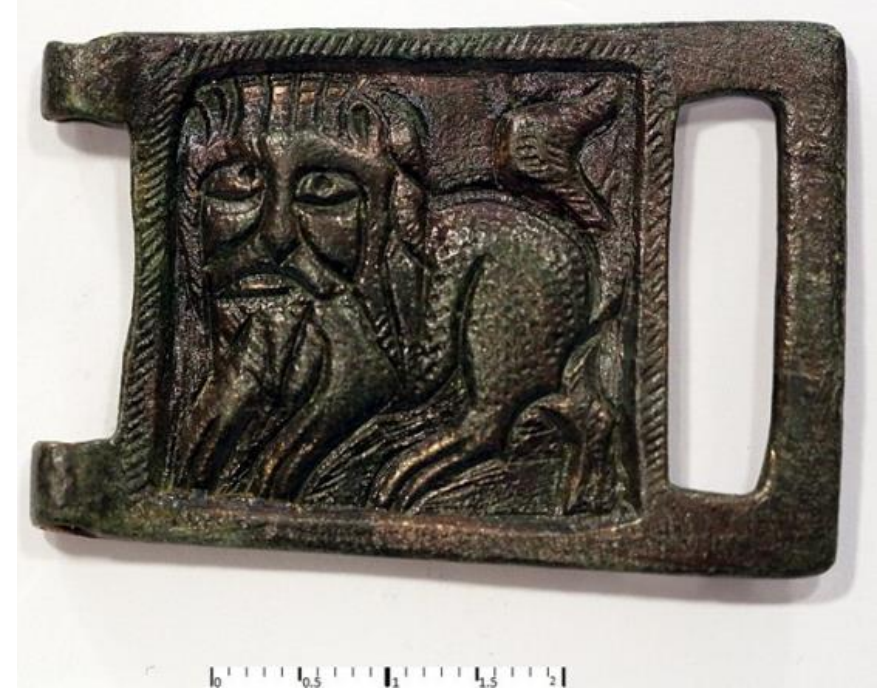

Resim 1: Kayseri Selçuklu Uygarlı̆̆ı Müzesi’nde Bulunan SUM361 Nolu Kemer Tokası

32 Hatice Ünlerşen, Kayseri Selçuklu Uygarlı̆̆ı Müzesi’nde Bulunan Kemer Tokalarl (Konya: Necmettin Erbakan Üniversitesi, Sosyal Bilimler Enstitüsü, Yüksek Lisans Tezi, 2015). 


$\begin{array}{llll}\text { ENVANTER NO } & : \text { SUM } 416 & \text { ESERİN CINSİ } & \text { : Bronz } \\ \text { BOYUTLARI } & : 3,2 \times 4,7 \mathrm{~cm} & \text { YAPIM TEKNİĞİ } & \text { : Döküm } \\ \text { BEZEME TEKNİKLERİ } & : \text { Kazıma } & \text { ESERİN DÖNEMİ } & \text { : Ortaçağ }\end{array}$

ESERIN TANIMI : Eser dikdörtgen şeklindedir. Eserin sağ tarafında kemer bağlantısı için yapılmış olan halka kırılıp kopmuştur. Solunda ise yine kemer bağlantısı için yapılmış olan iki küçük halka mevcuttur ve bu iki halkanın arasında olması gereken parçalar emarelerinden de anlaşılacağı üzere kopmuştur. Eser üzerinde kabartma olarak gövdesi ve başı profilden verilmiş bir pegasus figürü yer almaktadır. Figür koşar vaziyettedir. Gövdede noktalar, kuyruk ve kanatta ise çizgiler kazıma yoluyla bezenmiştir. Böylece figür üzerinde bir hareketlilik sağlanmıştır.

DEĞERLENDİRME : Pegasus figürünün yer aldığı kemer tokası incelendiğinde eserin 10.12. yy Bizans Dönemi olma ihtimali yüksektir. Figür esas itibariyle Hristiyan hikâyelerinde ve ikonografisinde çok kullanmış olmasının yanı sıra Afyon Amorium Kazısından çıkan ve Afyon Arkeoloji Müzesi'nde yer alan kemer tokalarıla karşılaştırıldığında eserlerin form, bezeme ve figür açısından birebir uyuştuğu görülmektedir.

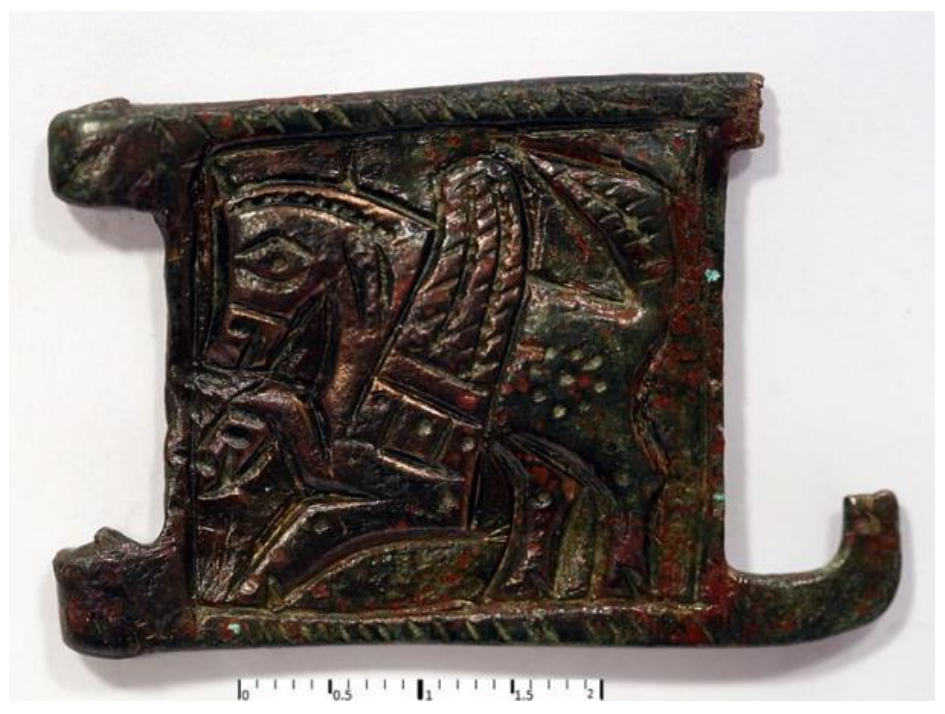

Resim 2: Kayseri Selçuklu Uygarlı̆̆ı Müzesi’nde Bulunan SUM416 Nolu Kemer Tokası 


\begin{tabular}{|c|c|c|c|}
\hline ENVANTER NO & : SUM 418 & ESERIN CINSSI & : Bronz \\
\hline BOYUTLARI & $: 3,2 \times 4,6 \mathrm{~cm}$ & YAPIM TEKNİĞİ & : Döküm \\
\hline BEZEME TEKNIKKLERİ & : Kazıma & ESERİN DÖNEMI & : Ortaçağ \\
\hline $\begin{array}{l}\text { ESERIN TANIMI } \\
\text { yapıldığı halka ortadan kırılı } \\
\text { halka bulunmaktadır. Fakat } \\
\text { üzerinde kabartma olarak b } \\
\text { fantastik hayvan koşar vazi }\end{array}$ & \multicolumn{3}{|c|}{$\begin{array}{l}\text { : Eser dikdörtgen bir formdadır. Eserin sağında kemer bağlantısının } \\
\text { p kopmuştur. Solda ise yine kemer bağlantısı için yapılmış olan iki küçük } \\
\text { iki halka arasında olması gereken diğer parçalar mevcut değildir. Eser } \\
\text { aşı ve gövdesi profilden verilmiş bir grifon figürü yer almaktadır. Bu } \\
\text { yette iken başını geri çevirmiştir. Kanatlarda kazıma tekniği daha derin } \\
\text { daha vüzevsel ve kırık cizgilerle hareketlilik sağlanmıstır. }\end{array}$} \\
\hline
\end{tabular}

DEĞERLENDİRME : Örnek eser incelendiğinde eser figür, form ve bezeme açısından Afyon Arkeoloji Müzesi'nde sergilenen eserler ile benzerliklerinden dolayı 10.-12. yy Bizans dönemi olarak tarihlendirmek mümkündür. Ayrıca bu fikri destekleyen Afyon Arkeoloji Müzesi’nde bulunan kemer tokaları örnek eserimize oldukça yakın özellikler göstermektedir.

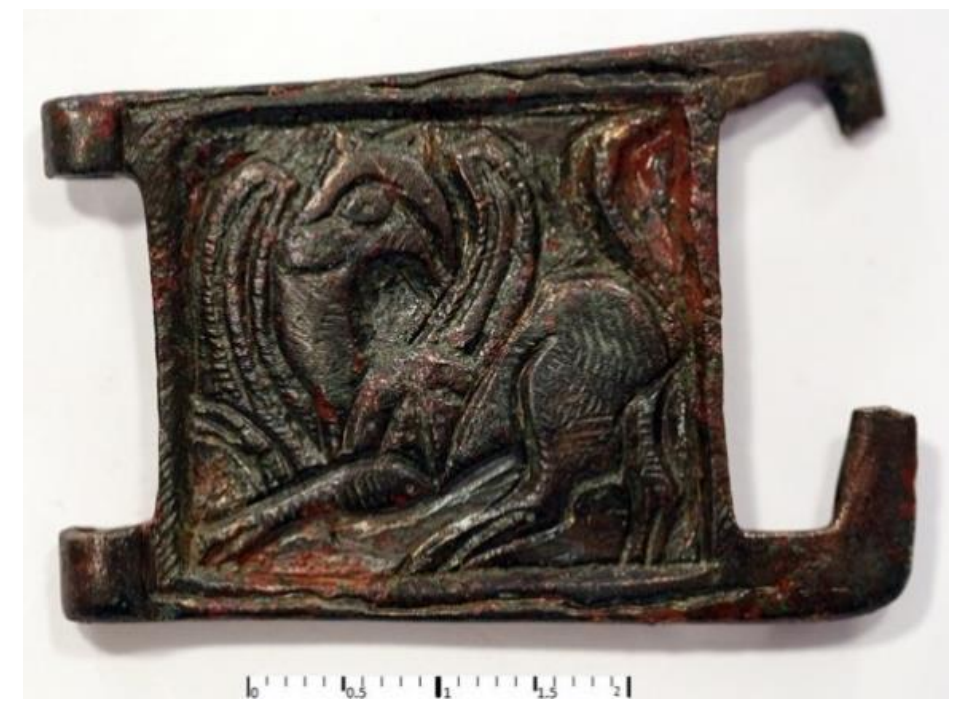

Resim 3: Kayseri Selçuklu Uygarlığı Müzesi'nde Bulunan SUM418 Nolu Kemer Tokası 


\begin{tabular}{|c|c|c|c|}
\hline ENVANTER NO & : SUM 400 & ESERIN CINSII & : Bronz \\
\hline BOYUTLARI & $: 2,6 \times 3 \mathrm{~cm}$ & YAPIM TEKNİĞİ & : Döküm \\
\hline BEZEME TEKNİKLERİ & : Kazıma & ESERIN DÖNEMI & : Ortaçağ \\
\hline $\begin{array}{l}\text { ESERIN TANIMI } \\
\text { Eserin sağında ve solunda } \\
\text { ulaşamamıştır. Eser üzerinde } \\
\text { dik, gözler badem, ağız açık } \\
\text { görülmektedir. Gövdede ka } \\
\text { görünümü verilmistir. Fioür s }\end{array}$ & \multicolumn{3}{|c|}{$\begin{array}{l}\text { : Envanter numarası } 400 \text { olan kemer tokamız dikdörtgen bir şekildedir. } \\
\text { olması gereken, kemer bağlantısı için yapılan halkalar günümüze } \\
\text { kabartma olarak çift başlı ejder figürü yer almaktadır. Ejderin kulaklar } \\
\text { ve dil çataldır. Birbirine dolanmış olan bu çift ejderin kuyruk uçları da } \\
\text { zzıma tekniğinden yararlanılarak lokma lokma desenlerle adeta pul } \\
\text { sade bir cerceve icine yerlestirilmistir. }\end{array}$} \\
\hline
\end{tabular}

DEĞERLENDİRME : Yukarıda özelliklerinden bahsedilen kemer tokasının üzerinde birbirine dolanmış iki ejder figürü yer almaktadır. Birbirine dolanmış ejderler genelde taş eserlerde sıkça karşılaşılmaktadır. Eserde yer alan ejderlerin gözlerinin iri badem şeklinde olması, kulaklarının dik ve çatal dillerinin bulunması 11.-12. yy Selçuklu dönemi ejderlerinde bulunan özellikleri yansıtmaktadır. Ayrıca figürün çerçeve içerisine yerleştirilmesi de bir Selçuklu dönemi özelliklerindendir. Tüm bu sebeplerden dolayı diyebiliriz ki eser 11.-12. yy Selçuklu dönemine yakın bulunmaktadır.

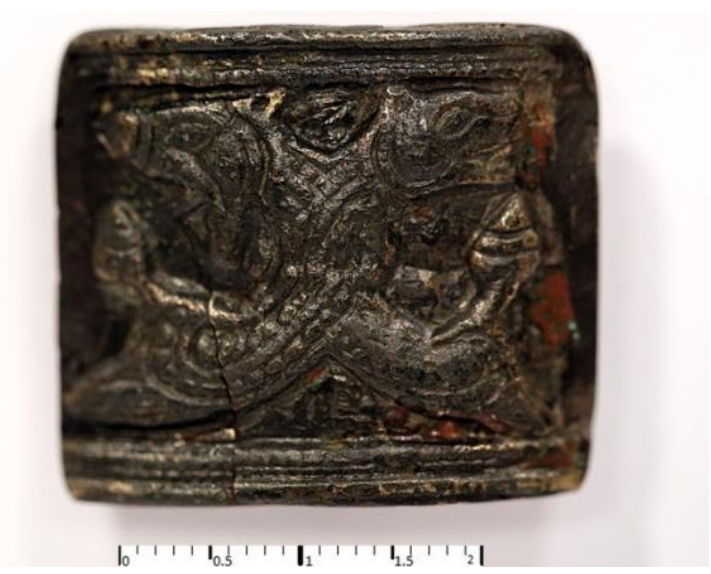

Resim 3: Kayseri Selçuklu Uygarlığı Müzesi’nde Bulunan SUM400 Nolu Kemer Tokası 


\begin{tabular}{|c|c|c|c|}
\hline ENVANTER NO & : SUM 460 & ESERIN CINNSİ & : Bronz \\
\hline BOYUTLARI & $: 2,9 \times 4,4 \mathrm{~cm}$ & YAPIM TEKNİĞİ & : Döküm \\
\hline BEZEME TEKNİKLERİ & : Kazıma & ESERIIN DÖNEMİ & : Ortaçağ \\
\hline $\begin{array}{l}\text { ESERIN TANIMI } \\
\text { kemerle olan bağlantının y } \\
\text { halka bulunmaktadır. Bu ik } \\
\text { eserde bir hayvan mücadel } \\
\text { hayvanda profilden verilmi } \\
\text { bacak arasından yukarı doğ } \\
\text { Altta bulunan boğanın acısı }\end{array}$ & \multicolumn{3}{|c|}{$\begin{array}{l}\text { : Dikdörtgen boyutlara sahip olan kemer tokasının sağ tarafında } \\
\text { 1lmasına yarayan halka ve solda da aynı işlem için yapılmış iki küçük } \\
\text { küçük halka arasındaki diğer parçalar mevcut değildir. İki figür yer alan } \\
\text { sahnesi işlenmiştir. Bu sahnede aslan boğaya saldırmış vaziyettedir. İk } \\
\text { ir. Yukarıda olan aslanın gözleri açık, sağ ön ayağı yukarıda, kuyruk ise } \\
\text { d kıvrılmıstır. Üzerinde bulunan noktalar kazıma tekniği ile işlenmiştir } \\
\text { ifade etmek için gözler kapalı, ağız oldukça açık ve beden teslim olmuş } \\
\text { irler çerçeve içerisine yerleştirilmiştir. }\end{array}$} \\
\hline
\end{tabular}

DEĞERLENDİRME : Türklerin ana yurdu olan Orta Asya'dan Anadolu'ya kadar gelmiş olan hayvan mücadele sahneleri çeşitli malzemeler üzerinde yaygın bir şekilde işlenmiştir. Ayrıca örnek eser üzerindeki figür, kompozisyon, işleme teknikleri 11.-12. yy Selçuklu dönemi olma ihtimalini kuvvetlendirmektedir.

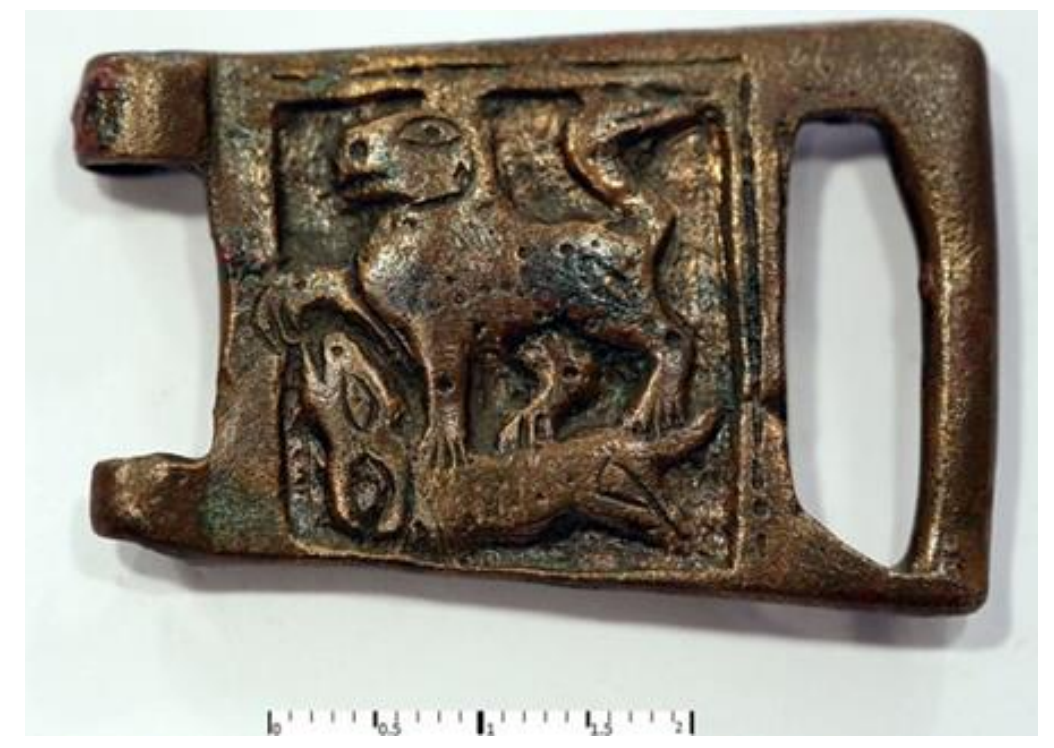

Resim 4: Kayseri Selçuklu Uygarlığı Müzesi’nde Bulunan SUM460 Nolu Kemer Tokası 


$\begin{array}{llll}\text { ENVANTER NO } & \text { : SUM } 391 & \text { ESERIN CINSİ } & \text { : Bronz } \\ \text { BOYUTLARI } & : 1,5 \times 1,8 \times 2,6 \mathrm{~cm} & \text { YAPIM TEKNIĞİ } & \text { : Döküm } \\ \text { BEZEME TEKNIKKLERİ } & : \text { Kazıma } & \text { ESERİN DÖNEMİ } & \text { : Ortaçă̆ }\end{array}$

ESERIN TANIMI : Eser dikdörtgen bir şekildedir. Tokanın iç kısmı boş olup dikdörtgen bir kutu şeklinde yapılmıştır. Kataloğumuzda bulunan diğer kemer tokalarına göre farklılık arz eden tokanın üzerinde kabartma olarak gövdesi ve başı profilden verilmiş bir tavus kuşu bulunmaktadır. Tavus kuşunun önünde yine kabartma olarak işlenmiş çiçek motifi yer almaktadır. Figür üzerinde kazıma tekniği uygulanarak detaylı bir süsleme yapılmıştır. Böylece esere gerçeklik boyutu katılmış ve aynı zamanda da hareketlilik sağlanmıştır.

DEĞERLENDİRME : Yukarıda bahsedilen eserin üzerinde bulunan tavus kuşunun işleniş niteliği ve figür özellikleri açısından Bizans Dönemi 10.-12. yy olarak tarihlendirmek mümkündür.

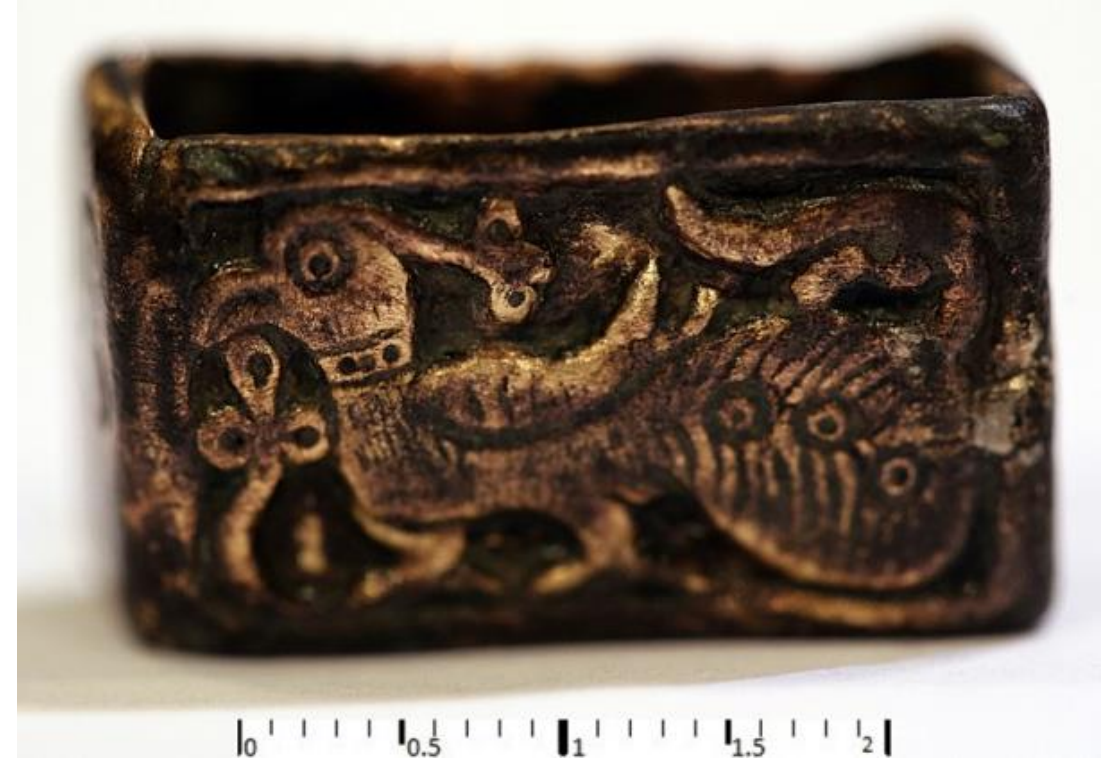

Resim 5: Kayseri Selçuklu Uygarllğı Müzesi'nde Bulunan SUM391 Nolu Kemer Tokası 


\section{DEĞERLENDİRME VE SONUÇ}

Dini, resmi ve hususi hayatta çok önemli bir yeri olan kemer tokaları, üzerine işlenmiş olan ikonografik boyutlar açısından ayrı bir anlam taşımaktadır. Genel olarak tarihi eserler (bu çalışma kapsamında kemer tokaları) üzerinde yer alan ikonografik semboller, farklı eserlerin ortak figürler içermesi, benzer yapım metotlarına veya yapı malzemesine sahip olması gibi özellikleri sayesinde, eserlerin dönemlerinin, bölgelerinin veya kültürlerinin karşılaştırılmasına imkân sağlar. Bu bağlamda Kayseri Selçuklu Uygarlığı Müzesi'nde bulunan kemer tokaları, her ne kadar müzedeki sergi alanlarında Selçuklu dönemine ait oldukları belirtilmişse de, bu çalışmada belirtilen eserlerin ikonografik boyutları benzer örnekler ile karşılaştırılarak bu olgunun doğruluğu irdelenmiştir.

Araştırma kapsamımızda olan Kayseri Selçuklu Uygarlığı Müzesi’nde bulunan kemer tokaları, üzerlerindeki figürler hasebiyle ikonografik boyutu öne çıkmış eserlerdir. Bu eserler üzerinde aslan, pegasus, grifon, ejder, hayvan mücadele sahnesi ve tavus kuşu yer almaktadır.

Aslan, genellikle güç, kuvvet, heybet ve metanet sembolü manasındadır. Çeşitli eserler üzerinde, kanatlı aslan, kuyruğu ejder ile son bulan aslan gibi farklı farklı aslan figürlerine rastlanmaktadir.

Hristiyan efsanelerinde aslan ölü doğup ölümünden üç gün sonra efendisi tarafindan nefes üflenerek hayata dönmektedir. Böylece aslan kıyametle ilişkilendirilerek yaşamın efendisi olarak kabul edilen Mesih'in sembolü olmuştur. Aslan aynı zamanda Hristiyan inancına göre Zülkifl Peygamber'de görülen dört hayvandan biridir. Zülkifl, evanjelist Mark'1n sembolüdür. Aslan, Hristiyan sanatında iyiyi temsil ettiği gibi kötüyü de temsil etmektedir. Ortaçağ inancına göre ise aslanın gözünün açık olması bir uyanıklık işareti olarak görülmektedir. ${ }^{33}$

Selçuklu Sanatında görülen aslan figürlerinin en temel ortak özellikleri iri badem gözler, dik kulaklar, büyük yassı bir burun hattı ile birleşen kaşlar, biraz aralıklı ağız ve şişkin yanaklardır. Baş kısmına oranla küçük tutulan gövdelerde bacaklar kaba işlenmiş bulunmaktadır. Baldır kısmı ise virgül biçiminde yapılarak belirginleştirilmektedir. ${ }^{34}$

Anadolu Selçuklu Sultan'1 II. Gıyaseddin Keyhüsrev'in yaptırdığı İncir Han portalinde yer alan aslan figürü aslan güneş kompozisyonuna bir örnektir. ${ }^{35}$ Ayrıca II. Gıyaseddin Keyhüsrev adına 1240 'ta bastırılan sikke üzerinde de aslan figürü ile güneş diski bulunmaktadır. ${ }^{36} \mathrm{Bu}$ sikke üzerindeki aslan figürü ile İncir Han portalindeki aslan figürünün kompozisyonu aynıdır. ${ }^{37}$

Kayseri Selçuklu Uygarlığı Müzesi'nde sergilenen SUM 361 envanter numaralı kemer tokası üzerinde yer alan aslan figürü, Selçuklu dönemine ait eserlerde görülen aslan figürü ile form ve bezeme açısından benzerlikler taşımaktadır. $\mathrm{Bu}$ eser, Bizans döneminde görülen aslan figürleri ile form (aslanın göz, kulak, kuyruk, adale ve yelesi) açısından farklılıklar göstermektedir. ${ }^{38}$

Pegasus, kanatlı at olarak bilinen fantastik bir hayvan figürüdür. Şamanlık inancının etkisi ile sanat eserlerine yansıyan pegasus figürü olarak 12 hayvanlı takvimde birbiri ardınca gelen yılların

\footnotetext{
${ }^{33}$ George Ferguson, Signs \& Symbols in Christian Art (NewYork: Oxford University Press, 1996), 21.

${ }^{34}$ Gönül Öney, “Anadolu Selçuk Mimarisinde Arslan Figürü”, Anadolu (Anatolia) 13 (1971), 195-203.

${ }^{35}$ Kurt Erdmann - Hanna Erdmann, Das Anatolische Karavansaray Des 13 Jahrhunderts Teil I (Berlin: Gebr. Mann Verlag, 1961), 110.

${ }^{36}$ İbrahim Artuk - Cevriye Artuk, İstanbul Arkeoloji Müzeleri Teşirdeki Islâmî Sikkeler Kataloğu I (İstanbul: Millî Eğitim Basimevi, 1971), 365.

${ }^{37}$ Ahmet Çaycı, Anadolu Selçuklu Sanatında Gezegen ve Burç Tasvirleri (Ankara: TC Kültür Bakanlığı, 2002), 53.

${ }^{38}$ Suzanne Lewis, "The Iconography of The Coptic Horseman in Byzantine Egypt," Journal of The American Research Center in Egypt 10 (1973), 27-63.
} 
durağını gösteren bir gök işareti olarak karşımıza çıkmaktadır. Kanatlı at, gök ve yıldız tanrılarının bineği olarak ölümden sonra asil ruhları cennete yükseltmektedir. Şamanizm inancının tezahürü ile ortaya çıkmış olan bu fantastik figür daha ziyade Antik Dönem sanatında görülmektedir. ${ }^{39}$

Türk-İslam sentezi neticesinde Orta Asya'dan Anadolu'ya kadar her türlü sanat eserinde karşılaşabileceğimiz pegasus figürü, Konya İnce Minare (Taş ve Ahşap Eserler) Müzesi'nde sergilenen taş bir eser üzerinde yer almaktadır. Ayrıca New York Metropolitan Sanat Müzesi (MET)'nde sergilenen Selçuklu dönemi luster kap üzerinde pegasus figürüne rastlanılmaktadır. ${ }^{40}$

Afyon Arkeoloji Müzesi'nde bulunan ve Amorium kazılarından müzeye intikal eden kemer tokalarının bir tipolojisini yapan M. Lightfood, levha üzerinde hayvan kabartmalı grifon ve pegasus figürlü kemer tokası için bir tarih belirtilmemekle beraber bazı kaynaklara göre Erken Bizans (6.-8. yy) dönemine ait olduğu düşünülmektedir. ${ }^{41}$

Kayseri Selçuklu Uygarlığı Müzesi'nde sergilenen SUM 416 envanter numaralı eser üzerinde pegasus figürü bulunmaktadır. Bu eser yukarıda bahsedilen örnekler ile karşılaştırıldığında Bizans dönemi eserleri ile form, bezeme ve teknik açısından benzerlik gösterdiği görülmektedir. Pegasus figüründeki atın gövdesi ve kanatlarındaki süslemelerin kazıma tekniği, atın duruşu, eserin imalatında kullanılan malzeme ve kompozisyon açısından eser Selçuklu dönemi eserlerinden ayrışmaktadır.

Grifon, birçok bölgede ve birçok kültür içerisinde geçirdiği bazı değişiklikler dışında yüzyıllar boyunca sanatın çeşitli alanlarında kullanılan fantastik bir hayvandır. Grifon genel olarak kuş grifon ve aslan grifon olarak yaygındır. ${ }^{42}$ Suriye'nin güneş tanrısı, Mısır'da güneş tanrısı ile olan ilişkisisi, Hindistan'da güneş kültürü ile olan ilişkisi grifon figürünün ne kadar değişik ülkelerde ve çeşitli şekillerde yayılma oranını göstermesi bakımından önemlidir.

Antikçağ sanatındaki fantastik varlıklar içinde dikkat çeken grifon, gövdesinin gücü ile tanınan aslandan, kafası gökyüzünün hâkimi kartaldan oluşmaktadır. Grifon, Hellen dilinde kıvrılmış anlamına gelen gryps ve Latincede bir akbaba çeşidinin adı olan gryphus kelimelerinden türetildiği düşünülmektedir. ${ }^{43}$

Daha önceleri üzerine atfedilen koruyuculuk vasfı M.S. 3. yy’dan sonra değişerek kıvrak, zeki ve hızlı yapıda bir canlı türü olarak anılan grifon diğer hayvanlarla savaşan veya birlikte avlanan sahnelerde resmedilmektedir. Bu tanımlamalara en güzel örnek ise Sicilya'nın Piazza Armerina Komünü Villa Romana del Casale'nin iç mekânındaki sütunlu avluda yer alan mozaiklerde grifonun yer aldığı av sahneleridir. ${ }^{44}$

Talbot Rice, “A New Province of Byzantine Art” isimli makalesinde İstanbul St. John Studion Manastırı (İmrahor Camii)'nda bulunan grifon figürlü eseri Bizans dönemi 12. yy olarak tarihlendirmektedir. ${ }^{45}$ Ephorate of Byzantine Antiquities'da bulunan 7680 envanter numaralı kemer

\footnotetext{
${ }^{39}$ Emel Esin, Orta Asya'dan Osmanlıya: Türk Sanatında İkonografik Motifler (İstanbul: Kabalcı Yayınevi, 2004), 279.

40 Javad Neyestani, “The Study of Astronomical Symbols of Golden Shades Potteries," Kasmera 45/1 (2017), 21-42.

${ }^{41}$ Mücahide Lightfood, “Afyon Arkeoloji Müzesi ve Amorium Kazılarında Bulunan Bizans Kemer Tokaları”, Türk Arkeoloji ve Etnografya Dergisi 3 (2003), 119-134.

${ }^{42}$ Göktürk Ömer Çakır, "Küçük Asya Sikkeleri'nde Grifon Tipleri”, Mediterranean Journal of Humanities 3/2 (2013), 31-44.

43 Jacqueline Picoche, Dictionnaire Etymologique Du Français (Paris: Le Robert, 1984), 197.

44 Şehnaz Eraslan, "İstanbul Büyük Saray Mozaiklerindeki Grifon Betimlemeleri: Roma Döneminin Benzer Örnekleriyle İkonografik ve Sanatsal İlişkisi”, Cedrus 2 (2014), 443-451.

45 D Talbot Rice, "A New Province of Byzantine Art", The Burlington Magazine for Connoisseurs 62/363 (1933), 279-280.
} 
tokası üzerinde kuş başlı koşar vaziyette ve başı arkaya dönük bir grifon figürü bulunmaktadır. Yele ve ayak kısımları kazıma tekniği ile bronz malzeme üzerine işlenmiştir. Dikdörtgen bir forma sahip kemer tokası 7. yüzyıl olarak tarihlendirilmektedir. ${ }^{46}$

Selçuklu dönemi sanat eserlerinde de karşılaşılan grifon figürü daha çok koruyuculuk vasfiyla ortaya çıkmaktadır. Çeşitli sanat dallarında karşılaşılan grifona örnek verecek olursak Berlin Müzesi'nde sergilenen bir stuko parçası üzerinde geyik, kentaur ve grifon figürü yer almaktadır. ${ }^{47}$ Topkapı Sarayı'nda sergilenen ve banisi bilinmeyen çelikten imal edilmiş ayna üzerinde de kanatlı grifon bulunmaktadır. Ayna, Ülker Erginsoy tarafından 13. yy Selçuklu dönemi aynası olarak tarihlendirilmektedir. ${ }^{48}$

Kayseri Selçuklu Uygarlığı Müzesi’nde SUM 418 envanter numarası ile sergilenmekte olan kemer tokası üzerinde kuş grifon yer almaktadır. Yukarıda Selçuklu ve Bizans ortaçağ dönemine ait verilen örneklerle karşılaştırıldığında bu eser duruş pozisyonu, başının kuş olması, kanatları ve kompozisyon açısından Bizans dönemi eserine daha yakın durmaktadır.

Ejder, Orta Asya, Uzak Doğu ve Çin sanatında çok kullanılan bir figürdür. Özellikle kozmolojik ve ikonografik boyutundan dolayı kullanım yaygınlığı oldukça geniştir. Gılgamış Destanı'nda ölümsüzlüğün sembolü, Helen-Roma uygarlıklarında şifa dağıtıcı, Hristiyan dünyasında Aziz George'nin ejderha ile mücadelesini anlatan hikâyede şeytanı ve dinsizliği, Selçuklu kervansaraylarında koruyucu, çeşmelerde ebedi hayat ve sonsuzluğun simgesi olmuştur. ${ }^{49}$ Aynı zamanda hem Çin hem de Orta Asya kozmolojilerinde bolluk-bereket, güç-kuvvet, yeniden doğuşun simgesi olmuştur. Orta Asya Kültürü'nde bu inancın temelinde Şamanizm etkisi hâkimdir. ${ }^{50}$

Türk kültüründe iki tür ejder sembolizmi yaygındır. Biri yer ejderi diğeri de gök ejderidir. Güce güç katmak, koruyuculuğunu bir kat daha artırmak gibi anlamlar yüklenen çift ejder figürü en çok tercih edilen ejderdir. Çift ejder bazen karşılıklı bazen ayakta durur vaziyette, bazen de her iki ucunda da başı olan ve gökyüzü takını temsil eden, bir birine veya ağaca dolanmış vaziyetlerde bulunmaktadır. Orta Asya inancının daha ziyade hissedildiği Selçuklu sanat eserlerinde ejder figürünün ortak özellikleri bulunmaktadır. Bu özellikler ise, uzun olan gövdelerin birbirine dolanmış ya da düğümlenmiş ve her iki uçta da birer başın yer almış olmasıdır. Baş kısmında ise sivri kulaklar, iri badem gözler ve ağız kısmı açıktır. ${ }^{51}$ Örneğin; Konya İnce Minare (Taş ve Ahşap Eserler) Müzesi’nde bulunan ve Selçuklu Dönemi 13. yüzyıl olarak tarihlendirilen taş eserin merkezinde on dilimli rozet, ikinci halkada güneş diski, üçüncü halkada da on iki kollu yıldız kompozisyonu ve bu tasvirin sağ ve solunda simetrik olarak yerleştirilmiş iki adet ejder figürü mevcuttur. ${ }^{52}$ Afyon Müzesi'nde 213 envanter numarası ile sergilenmekte olan mezar taşının üzerinde de gövdeleri birbirine dolanmış çift ejder figürü yer almaktadır. Eser 13. yüzyıl olarak tarihlendirilmektedir. ${ }^{53}$

\footnotetext{
${ }^{46}$ Dēmētra Papanikola-Bakirtzē, Everyday Life in Byzantium (Athens: Hellenic Ministry of Culture, 2002 ), 485.

47 Friedrich Sarre, Erzeugnisse Islamischer Kunst II Seldschukische Kleinkunst (Berlin: Druck Von H.S. Hermann, 1909), 23.

${ }^{48}$ Ülker Erginsoy, İslam Maden Sanatının Gelişmesi: Başlangıcından Anadolu Selçuklularının Sonuna Kadar (İstanbul: Kültür Bakanlığı, 1978), 462.

49 Selman Kardeşlik, "Vakıflar Halı Müzesinde Selçuklu ve Selçuklu Geleneğindeki Halılarda Kozmolojik ve İkonografik Boyut,” Vakıf Restorasyon Yıllı̆̆ı Dergisi 2 (2011), 73-90.

${ }^{50}$ Gönül Öney, “Anadolu Selçuk Sanatında Ejder Figürleri”, Belleten 33/130 (1969), 171-192.

${ }^{51}$ Öney, “Anadolu Selçuk Sanatında Ejder Figürleri”, 171-192.

${ }_{52}^{5}$ Çayc1, Anadolu Selçuklu Sanatında Gezegen ve Burç Tasvirleri, 58.

${ }^{53}$ Katharina Otto-Dorn, "Türkische Grabsteine Mit Figurenreliefs Aus Kleinasien”, Ars Orientalis 3 (1959), 6376.
} 
Topkap1 Sarayı'nda 2/1792 envanter numarasıyla sergilenmekte olan 13. yüzyıl Selçuklu aynası üzerinde ejder figürü bulunmaktadır. ${ }^{54}$

M. Alison Frantz'ın Akritas and Dragon adlı makalesinde Akritas'ın elinde kılıç ile bir ejderhayı avlama sahnesi yer alan Bizans dönemine ait çömlek bir eser incelenmektedir. Eser üzerinde yer alan tek ejder, uzun, kendi etrafında kıvrılmış, ağzı açık, kulaklar dik ve gözler iri vaziyette resmedilmektedir. ${ }^{55}$

Kayseri Selçuklu Uygarlığı Müzesinde SUM 400 envanter numarası ile sergilenmekte olan kemer tokasında vücudu birbirine dolanmış iki ejder figürü bulunmaktadır. Eser üzerinde yer alan iki ejderin birbirine dolanma kompozisyonu Topkapı Sarayında 13. yy. Selçuklu dönemi aynası üzerindeki figürün kompozisyonu ile oldukça ciddi benzerlikler içermektedir. Bizans dönemi eserlerinde ise daha ziyade tek bir ejderin kendi bünyesinde kıvrıldığı kompozisyonlar yer almaktadır.

İnsanoğlunun yaşam serüveni içerisinde ister ehli ister yabani olsun hep hayvanlar bulunmaktadır. Hayvanlardan fayda sağlamaları ya da onlardan korunmaları yüzyıllar boyunca değişmez bir gerçek olmuştur. Ebette insanın hayvanlarla birlikte yaşama gayreti onları daha iyi tanımalarına ve daha iyi gözlemlemeleri neticesini doğurmuştur. Bu kadar yakından gözlemlenen hayvanlar âlemi birçok sanat eseri üzerinde karşımıza çıkmaktadır. Orta Asya'dan günümüze kadar süre gelen hayvan mücadele sahneleri toplum tarafindan çok kabul görmüştür. Saldırı sahnelerinde genellikle aslan-grifon, kartal-grifon, kaplan, pars v.b. hayvanların çeşitli cinslerdeki geyik, dağ keçisi, at, koyun gibi toynaklı ve otçul hayvanlara saldırdıkları görülmektedir. ${ }^{56}$

Hayvan mücadele sahnelerinin başlangıcı çok eskilere dayanmaktadır. Özellikle at-koşum takımlarında, kale, köprü gibi taş eserler üzerinde ve kemer tokalarında daha sıklıkla rastlanılan bir kompozisyondur.

Yumuktepe Höyügü Kazısı'nda ortaya çıkmış olan bronz bir kemer tokası üzerinde üçlü bir grup oluşturan hayvan mücadele sahnesi yer almaktadır. Boğa figürünün üzerinde bir grifon ve karşısında ayakta duran bir aslan kabartma olarak işlenmiştir. Söz konusu eser Ortaçağ olarak tarihlendirilmektedir. ${ }^{57}$ Konya İnce Minare (Taş ve Ahşap Eserler) Müzesi'nde 891 envanter numaras1 ile sergilenen taş eserde aslan-boğa mücadelesi yer almaktadır. ${ }^{58}$

Kayseri Selçuklu Uygarlığı Müzesinde SUM 460 envanter numarası ile sergilenen ve üzerinde hayvan mücadele sahnesi yer alan kemer tokası Selçuklu dönemi eserleri ile benzerlikler arz etmektedir. Eser üzerinde bulunan hayvanların formları ve mücadele sahnesinin kompozisyonu daha ziyade Selçuklu dönemi eserlerinde karşılaşılmaktadır. Orta Asya'dan gelen hayvan mücadele kompozisyonu Selçuklularda da eserler üzerinde sıklıkla kullanılmıştır.

Tavus kuşunun jeoloji kitaplarına göre ana vatanı Hindistan'dır. Hint mitolojisinde Skanda (veya Kumara)'nın simgesidir. Tavus kuşunun kuyruğu Sanskritçede sahasraksha yani bin gözlü

\footnotetext{
${ }^{54}$ Nilgün Çevrimli, "Değişik İşlevli Bir Grup Madeni Eser Örnekleri Üzerinde Görülen Ejder Figürleri Hakkında Bir Değerlendirme”, Vaklflar Dergisi 37 (2012), 193-222.

${ }^{55}$ M Alison Frantz, “Akritas And The Dragons", Hesperia: The Journal of The American School of Classical Studies at Athens 10/1 (1941), 9-13.

${ }^{56}$ Yaşar Çoruhlu, Türk Sanatı'nda Hayvan Sembolizmi (Konya: Kömen Yayınları, 2014), 169.

57 Gülgün Köroğlu, "Yumuktepe Höyüğü Kazılarından Ortaçağ Takıları", XIII. Ortaçă̆ ve Türk Dönemi Kazıları ve Sanat Tarihi Araştırmaları Sempozyumu Bildirileri (İstanbul: Pamukkale Üniversitesi, 2009), 417426.

${ }^{58}$ Eva Baer, “Group of Seljuq Figural Bas Reliefs”, Oriens 20 (1967), 107-124.
} 
anlamına gelmektedir. Yelpaze biçiminde açılan kuyruğu yine Hint mitolojisine göre yıldızlarla bezenmiş gökyüzünün simgesidir. ${ }^{59}$

Türklerde Tanrı kuşu, ala kuş veya gelin kuşu olarak da isimlendirilen tavus kuşu, Büyük İskender'in Hindistan topraklarından Avrupa merkezine taşıdığı düşünülen kuşlardandır. Güzellik timsali olması ve bakanları cezbettiği düşünülmesi tavus kuşunun cennet kuşu adı ile de anılmasına sebep olmuştur. ${ }^{60}$

Hristiyan sanatında tavus kuşu ölümsüzlüğün sembolü olarak anılır. Bu simgecilik tavus kuşunun etinin geç çürüdüğü inancından ileri gelmektedir. Kuyruğundaki yüzlerce göz ile her şeyi gördüğü düşünülmektedir. Ayrıca Hristiyanlıkta en çok tanınan azizelerden biri olan Azize Barbara'nın da simgesidir. ${ }^{61}$

Konya'da Bizans dönemine ait olan Geç Antik Dönem kiliselerinden Alibey Höyük ile Tatköy Manastır kiliselerinin zemin mozaiklerinde tavus kuşu figürleri yer almaktadır. Alibey Höyük Kilisesi'nde tavus kuşları bir havuzun iki yanına karşılıklı durur vaziyette yerleştirilmiş iken, Tatköy Manastır Kilisesi'ndeki tavus kuşları ise bir kantharosun iki yanında bulunmaktadır. ${ }^{62}$

Hristiyan menşeili olduğu kabul edilen tavus kuşu figürü Bizans Dönemi sanat eserlerinde sıkça karşılaşılan bir figürdür. Ravenna Başpsikopos Theodoros'un Lahdi'nde simetrik olarak iki tavus kuşu bulunmaktadır. Bu lahit 7. yüzyıla tarihlendirilmektedir. ${ }^{63}$ Berlin Bode Müzesi'nde bir kaptan su içen iki tavus kuşu işlenen mermer bir korkuluk ise 6. yüzyıla aittir. Selçuklu Dönemi sanat eserlerinde de zaman zaman karşılaşılan tavus kuşu figürü Konya Köşkü’nden getirilen ve Karatay Müzesi'nde sergilenen raf nişinin köşelerinde görülmektedir. Benzer örneklere fresko ve mozaiklerde de rastlanılmaktadır.

Kayseri Selçuklu Uygarlığı Müzesinde SUM 391 envanter numarası ile tavus kuşu figürlü bir kemer tokası sergilenmektedir. Selçuklu dönemi eserlerinde çokça tercih edilmeyen bu figür Bizans dönemi eserlerinde daha ayrıntılı bir şekilde eser üzerine işlenmektedir. Eser üzerindeki tavus kuşunun kuyruk, ağız ve bacak yapısı Bizans dönemi eserleriyle benzeşmektedir.

Kemer tokalarının tarihi seyri içerisinde araştırma alanımız olan Kayseri Selçuklu Uygarlığı Müzesi'nde yer alan kemer tokalarından öne çıkan eserlerin eldeki veriler ışığında bu dönemlere olan benzerlikleri incelenerek yaklaşık dönem tespiti yapılmaya çalışılmıştır. Örnek eserler üzerine, aslan, grifon, pegasus, ejder, hayvan mücadele sahnesi ve tavus kuşu gibi çeşitli figürler bezenmiştir. Eserlerin malzemesi bronzdandır. Yapım tekniği olarak döküm, bezeme tekniği olarak da kazıma ve kalıpla kabartma teknikleri kullanılmıştır.

Aynı dönemi paylaşan ve komşu topraklarda yaşayan Bizans ve Selçuklu Devletleri bir kültür paylaşımı içerisinde bulunmuşlardır. Bu etkileşim elbette beraberinde benzerliği de doğurmuştur. Günümüzde var olan kemer tokalarının birçoğuna bakıldığında bunun Selçuklulara mı yoksa Bizanslılara $\mathrm{m}$ ait olduğu tam net belirlenememektedir. Toka üzerinde herhangi bir dini konu ve şekil yoksa tasnifte sorun yaşanmaktadır.

\footnotetext{
${ }^{59}$ Ebru Parman, "Bizans Sanatında Tavus Kuşu İkonografisi”, Sanat Tarihinde İkonografik Araştırmalar Güner Inal'a Armağan (1993), 387-412.

${ }^{60}$ Ömür Ceylan, "Tavus”, Türkiye Diyanet Vakfi İslâm Ansiklopedisi (Ankara: TDV Yayınları, 2011), 184-185.

${ }^{61}$ Ferguson, Signs \& Symbols in Christian Art, 23.

${ }^{62}$ İlker Mete Mimiroğlu, Konya 'nın Bizans Dönemi Dini Mimarisi (Konya: Selçuk Üniversitesi, Sosyal Bilimler Enstitüsü, Doktora Tezi, 2015), 320-321.

${ }^{63}$ Edward M. Schoolman, "Reassessing The Sarcophagi of Ravenna”, Dumbarton Oaks Papers 67 (2013), 4974.
} 
Küçük objelerin kolay yer değiştirebilmesi, ustaların kendi görgü ve becerilerini gittikleri bölgelerde devam ettirmeleri ya da kültürel etkileşim gibi durumların karşısında, bu tür objelerin tarihi hakkında net bir yargıya varmak zor olmaktadır. Herhangi bir kemer tokası kesin bir delil bulunmadığı için Bizanslılara ait denilemediği gibi elbette Selçuklulara aittir de denilemez. Ancak bahsedilen dönemi belirli olan eserler ile Kayseri Selçuklu Uygarlığı Müzesi’ndeki kemer tokalarının benzerliği göz ardı edilemez.

İncelenen eserler için dar bir zaman dilimi belirlenemese de geniş bir zaman aralığ olarak Selçuklu ve Bizans medeniyetlerinin Anadolu'da hüküm sürdüğü Orta Çağ dönemi teklif etmek mümkündür.

Küçük obje tarzındaki sanat eserlerinin kaybolma olasılı̆̆ı, yer ve el değiştirmesinin kolaylığ1, yapılan kazı çalışmalarının yetersizliği bu objelerin nereye, hangi zamana ve kime ait olduğu gibi soruların cevapları için yetersiz kalmaktadır. Bundan sonra ortaya çıkacak olan eserler karanlığa mutlaka 1şık tutacaktır.

\section{KAYNAKÇA}

Allan, James W. Nishapur: Metalwork of The Early Islamic Period. NewYork: Metropolitan Museum of Art, 1982.

Arlı, Mustafa. Beypazarı’nda Dövme Bakırcllık. İstanbul: Kültür ve Turizim Bakanlığı Millî Folklor Araştırma Dairesi Yayınları, 1984.

Artuk, İbrahim - Artuk, Cevriye. İstanbul Arkeoloji Müzeleri Teşirdeki Islâmî Sikkeler Kataloğu I. İstanbul: Millî Eğitim Basimevi, 1971.

Baer, Eva. "Group of Seljuq Figural Bas Reliefs". Oriens 20 (1967), 107-124.

Çakır, Göktürk Ömer. "Küçük Asya Sikkeleri’nde Grifon Tipleri”. Mediterranean Journal of Humanities 3/2 (2013), 31-44.

Calmeyer, Peter. "Belts". Encyclopedia Iranica. 130-136. Encyclopædia Iranica Foundation, 1989.

Çaycı, Ahmet. Anadolu Selçuklu Sanatında Gezegen ve Burç Tasvirleri. Ankara: TC Kültür Bakanlığı, 2002.

Çevrimli, Nilgün. "Değişik İşlevli Bir Grup Madeni Eser Örnekleri Üzerinde Görülen Ejder Figürleri Hakkında Bir Değerlendirme". Vakıflar Dergisi 37 (2012), 193-222.

Ceylan, Ömür. "Tavus”. Türkiye Diyanet Vakfı İslâm Ansiklopedisi. 184-185. Ankara: TDV Yayınları, 2011.

Çoruhlu, Yaşar. Türk Sanatı'nda Hayvan Sembolizmi. Konya: Kömen Yayınları, 2014.

Diyarbekirli, Nejat. Hun Sanatı. İstanbul: Milli Eğitim Bakanlığı Kültür Yayınları, 1972.

Eraslan, Şehnaz. "İstanbul Büyük Saray Mozaiklerindeki Grifon Betimlemeleri: Roma Döneminin Benzer Örnekleriyle İkonografik ve Sanatsal İlişkisi”. Cedrus 2 (2014), 443-451.

Erdmann, Kurt - Erdmann, Hanna. Das Anatolische Karavansaray Des 13 Jahrhunderts Teil I. Berlin: Gebr. Mann Verlag, 1961.

Erginsoy, Ülker. İslam Maden Sanatının Gelişmesi: Başlangıcından Anadolu Selçuklularının Sonuna Kadar. İstanbul: Kültür Bakanlığı, 1978.

Erginsoy, Ülker. “Maden Sanatı”. Eczacıbaşı Sanat Ansiklopedisi. 1138-1147. Yapı-Endüstri Merkezi Yayınları, 1997.

Eruz, Fulya. Konuşan Maden: Tombak ve Gümüş Madeni Eserler Koleksiyonu. İstanbul: Yapı Kredi Yayınları, 1993.

Esin, Emel. Orta Asya'dan Osmanliya: Türk Sanatında İkonografik Motifler. İstanbul: Kabalcı Yayınevi, 2004.

Ferguson, George. Signs \& Symbols in Christian Art. NewYork: Oxford University Press, 1996.

Frantz, M Alison. "Akritas And The Dragons". Hesperia: The Journal of The American School of Classical Studies at Athens 10/1 (1941), 9-13. 
Karamağaralı, Nakış. “Ani’de 2002 Yılında Ortaya Çıkarılan Yapı ve İçinde Bulunan Define”. Erdem 55 (2009), 93-115.

Kardeşlik, Selman. "Vakıflar Halı Müzesinde Selçuklu ve Selçuklu Geleneğindeki Halılarda Kozmolojik ve İkonografik Boyut”. Vakıf Restorasyon Yıllı̆̆ı Dergisi 2 (2011), 73-90.

Kayaoğlu, İzzet Gündağ. Bakır Kap Yapım ve Teknikleri: I. Dövme Tekniği. İstanbul: Anadolu Sanat Yayınları, 1984.

Kayaoğlu, İzzet Gündağ. Türkiye’de Sanatın Bugünü ve Yarını. Ankara: Hacettepe Üniversitesi Güzel Sanatlar Fakültesi Yayınları, 1985.

Kazhdan, Alexander. "Belt." The Oxford Dictionary of Byzantium. 280. Oxford University Press, 1991.

Keller, Hans - Eichoff, Klaus. Bakır ve Bakır Alaşımları, çev. Şefik Güleç. İstanbul: İ.T.Ü. Yayını, 1969.

Kerametli, Can. “Türk Maden Sanatı”. Türk Yurdu 10 (1966), 14-32.

Köroğlu, Gülgün. “A Group of Belt Buckles From The Haluk Perk Museum Possible Belonging to The Anatolian Seljuks”. 13th International Congress of Turkish Art. 393-407. Budapest: Hungarian National Museum, 2009.

Köroğlu, Gülgün. Anadolu Uygarlıklarında Takı. İstanbul: Türk Eskiçağ Bilimleri Enstitüsü Yayınları, 2004.

Köroğlu, Gülgün. “Bizans’ta Kadın ve Kadın Takıları”. Osmanlı Bankası Arşiv ve Araştırma Merkezi 24 (2010), $1-15$.

Köroğlu, Gülgün. "Yumuktepe Höyüğü Kazılarından Ortaçağ Takıları”. XIII. Ortaçă̆ ve Türk Dönemi Kazıları ve Sanat Tarihi Araştırmaları Sempozyumu Bildirileri. 417-426. İstanbul: Pamukkale Üniversitesi, 2009.

Kuşoğlu, Mehmet Zeki. “Dünden Bugüne Gümüş Kakma Sanatımız”. İlgi Dergisi 48 (1987), 32-35.

Kuşoğlu, Mehmet Zeki. “Osmanlı Kemer ve Tokaları”. Dünkü Sanatımız Kültürümüz 279 (1994), 53-58.

Kuşoğlu, Mehmet Zeki. Resimli Ansiklopedik Kuyumculuk ve Maden Terimleri Sözlüğü. İstanbul: Ötüken Neşriyat, 2006.

Kuşoğlu, Mehmet Zeki. “Telkâri”. İlgi Dergisi 45 (1986), 31-35.

Lewis, Suzanne. "The Iconography of The Coptic Horseman in Byzantine Egypt". Journal of The American Research Center in Egypt 10 (1973), 27-63.

Lightfood, Mücahide. “Afyon Arkeoloji Müzesi ve Amorium Kazılarında Bulunan Bizans Kemer Tokaları”. Türk Arkeoloji ve Etnografya Dergisi 3 (2003), 119-134.

Maryon, Herbert. "Metal Working in The Ancient World”. American Journal of Archaeology 53/2 (1949), 93125.

Mimiroğlu, İlker Mete. Konya’nın Bizans Dönemi Dini Mimarisi. Konya: Selçuk Üniversitesi, Sosyal Bilimler Enstitüsü, Doktora Tezi, 2015.

Neyestani, Javad. “The Study of Astronomical Symbols of Golden Shades Potteries”. Kasmera 45/1 (2017), 2142.

Öney, Gönül. “Anadolu Selçuk Mimarisinde Arslan Figürü”. Anadolu (Anatolia) 13 (1971), 195-203.

Öney, Gönül. “Anadolu Selçuk Sanatında Ejder Figürleri”. Belleten 33/130 (1969), 171-192.

Otto-Dorn, Katharina. "Türkische Grabsteine Mit Figurenreliefs Aus Kleinasien”. Ars Orientalis 3 (1959), 6376.

Özbağı, Tevhide. “Geleneksel Türk Takıları”. Türkler Ansiklopedisi. 785-799. Yeni Türkiye Yay, 2002.

Papanikola-Bakirtzē, Dēmētra. Everyday Life in Byzantium. Athens: Hellenic Ministry of Culture, 2002.

Parani, Maria G. Optional Extras or Necessary Elements? Middle And Late Byzantine Male Dress Accessories.

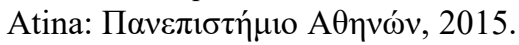

Parman, Ebru. "Bizans Sanatında Tavus Kuşu İkonografisi”. Sanat Tarihinde İkonografik Araştırmalar, Güner Inal'a Armağan (1993), 387-412.

Picoche, Jacqueline. Dictionnaire Etymologique Du Français. Paris: Le Robert, 1984.

Rachel, Ward. Islamic Metalwork. London: British Museum Press, 1993.

Rice, D Talbot. “A New Province of Byzantine Art”. The Burlington Magazine for Connoisseurs 62/363 (1933), 
279-280.

Sarre, Friedrich. Erzeugnisse Islamischer Kunst II Seldschukische Kleinkunst. Berlin: Druck Von H.S. Hermann, 1909.

Schoolman, Edward M. "Reassessing The Sarcophagi of Ravenna”. Dumbarton Oaks Papers 67 (2013), 49-74.

Süslü, Özden. Tasvirlere Göre Anadolu Selçuklu Klyafetleri. Ankara: Atatürk Kültür, Dil ve Tarih Yüksek Kurumu, 1989.

Ünlerşen, Hatice. Kayseri Selçuklu Uygarlı̆̆ı Müzesi’nde Bulunan Kemer Tokaları. Konya: Necmettin Erbakan Üniversitesi, Yüksek Lisans Tezi, 2015.

Yavaş, Alptekin. "Kubad-Abad Sarayında Bulunan Kemer ve Ask1 Tokalar1.” Turkish Studies-International Periodical For The Languages, Literature and History of Turkish or Turkic 7/3 (2012), 2635-2648. 